[RADIOCARBON, VOL 31, No. 1, 1989, P 7-13]

\title{
A RADIOCARBON SEQUENCE FROM THE TOAGA SITE, OFU ISLAND, AMERICAN SAMOA
}

\author{
P V KIRCH*, T L HUNT** and JASON TYLER*
}

The Samoan Archipelago occupies a critical position for understanding the dispersal of early Austronesian-speaking peoples into the southwestern Pacific, including the initial colonization by humans of the Polynesian triangle. To date, the most easterly reported site of the Lapita cultural complex (Green, 1979; Kirch, 1984; Kirch \& Hunt, 1988) is the Mulifanua site on Upolu Island, Western Samoa (Green \& Davidson, 1974). Lapita colonists settled the larger, western Samoan Islands by the end of the second millennium BC. Archaeologic and linguistic evidence also suggest that the islands of Eastern Polynesia (eg, Marquesas, Society and Cook Islands) were settled, at least in part, from Samoa. However, the timing of this movement into Eastern Polynesia has not yet been dated to earlier than ca $150 \mathrm{BC}$ on the basis of radiocarbon dating of cultural materials from the Marquesas Islands (Kirch, 1986; Ottino, 1985). This has raised the issue of whether there was a "long pause" between the settlement of Samoa (and the other islands of Western Polynesia, such as Tonga, Futuna, and 'Uvea) and that of Eastern Polynesia (Irwin, 1981; Kirch, 1986; Terrell, 1986).

Until recently, the remote Manu'a Islands at the eastern end of the Samoan Archipelago had not been well explored archaeologically, even though, on a geographic basis, they would have provided the most likely point of departure for early voyaging canoes bound on eastward courses of discovery and colonization (Finney, 1985, 1988). In 1986 and 1987, the authors initiated a long-term archaeological project in the Manu'a group (Hunt \& Kirch, 1988), leading to the discovery of several early sites containing pottery assemblages. The Toaga site (AS-13-1) on Ofu Island, in particular, contains a deeply-stratified sequence of cultural occupations. In this paper, we report a sequence of seven ${ }^{14} \mathrm{C}$ age determinations from the Toaga site, providing the first radiometric framework for eastern Samoan prehistory. Following a brief summary of the Toaga site, and the radiocarbon dates, the implications of this sequence for Polynesian prehistory are discussed.

\section{THE TOAGA SITE}

The Toaga site (AS-13-1) is located on the southeastern coast of Ofu Island $\left(14^{\circ} 10^{\prime} 55^{\prime \prime} \mathrm{S}, 169^{\circ} 39^{\prime} 0^{\prime \prime} \mathrm{E}\right)$, a very steep remnant shield volcano of Pleistocene age. The site is situated within the geomorphologic context of a narrow coastal plain constructed primarily of unconsolidated marine calcareous sands, aith alternating terriginous colluvial deposits at the base of the steep volcanic slope. A geomorphologic analysis of the site stratigraphy, to be presented in detail elsewhere (Kirch, Hunt \& Tyler, ms in preparation), indicates that this coastal plain has prograded substantially within the late Holocene. At ca $4000 \mathrm{BP}$, immediately prior to initial human settle-

* The Burke Museum, University of Washington, Seattle, Washington 98195

** Department of Anthropology, University of Hawaii, Honolulu, Hawaii 96822 
ment, the shoreline was much closer to the volcanic cliffs than at present, and occupation was confined to the formerly narrow beach ridge.

The site was discovered during reconnaissance survey in 1986, when inspection of a bulldozed landfill operation revealed Polynesian Plainware ceramics in a buried occupation horizon (Hunt \& Kirch, 1988). A test pit was excavated, and a sample of marine shell midden dated to $2350 \pm 50$ (Beta-19742) (Hunt \& Kirch, 1987). In 1986, expanded excavations were undertaken at the site in undisturbed areas of the coastal plain east of the landfill. A total of $13 \mathrm{~m}^{2}$ was excavated, $7 \mathrm{~m}^{2}$ in a main stratigraphic trench, and 6 test excavation units. The main trench revealed a deep stratigraphic sequence (total excavation depth $3.5 \mathrm{~m}$ ), with the following principal stratigraphic units: Layer I, massive deposit of colluvium; Layer II, calcareous sand representing dune-beach ridge depositional environment prior to coastal progradation, and incorporating Layer IIB, an occupation horizon with Polynesian Plainware ceramics; Layer III, massive deposit of silty-clay colluvium; Layer IV, mixed calcareous sand with reddish colluvial clay; Layer V, basal calcareous beach deposit, containing isolated sherds of thin, fine ceramic ware.

Layer IIB of the Toaga site yielded one of the largest samples of Polynesian Plainware ceramics and associated cultural materials (fishhooks, ornaments, other artifacts, as well as vertebrate and molluscan faunal remains) from the Samoan Archipelago. Thus, it is of substantial significance for our understanding of Western Polynesian prehistory. The small thin-ware sherds from Layer $\mathrm{V}$ represent an earlier ceramic phase of uncertain, but probable Lapita, affinity. The site also incorporates later aceramic prehistoric occupations in Layer I, overlying the main Polynesian Plainware phase (Layer IIB). In short, the Toaga site encapsulates within its sequence virtually the entire span of Samoan prehistory.

\section{THE RADIOCARBON SEQUENCE FROM TOAGA}

The seven ${ }^{14} \mathrm{C}$ samples from the Toaga site were selected from key stratigraphic contexts so as to provide a chronologic framework for the site from initial human occupation up through late prehistory. Six samples consist of marine shell, naturally deposited but in direct association with ceramic sherds (Beta-25035 and -25673), and culturally-modified food remains (Beta-25034, -25033, -26463 and -26465). Sample Beta-26464 consisted of wood charcoal fragments in association with Polynesian Plainware pottery.

${ }^{14} \mathrm{C}$ measurements were performed by Beta Analytic, Inc. Shell samples were pretreated by etching away the outer layers with dilute acid. The samples were then attacked with further acid to produce carbon dioxide, which was used as the carbon source (M Tamers, pers commun, 21 July 1988). The charcoal sample was picked for rootlets, and then given an acid, alkali and acid series of soakings. Benzene syntheses and counting of all samples proceeded normally. Charcoal sample, Beta-26464, which consisted of only $0.2 \mathrm{~g}$ of final carbon after pretreatment, was given extended counting time (four times the normal amount) to reduce statistical error as much as prac- 
ticable. The ${ }^{13} \mathrm{C} /{ }^{14} \mathrm{C}$ ratios were measured for all samples to establish ${ }^{13} \mathrm{C}$ adjusted, "conventional ${ }^{14} \mathrm{C}$ ages" (Stuiver \& Polach, 1977). These conventional age determinations, ${ }^{13} \mathrm{C}$ values, and details of all samples are presented at the end of this paper.

Corrections for specific ${ }^{14} \mathrm{C}$ activity, and for the marine reservoir effect taking into account regional ocean variation ( $\Delta R$ estimate), as well as calibration for secular effects, were made following the recent work of Stuiver, Pearson and Braziunas (1986) for the marine shell samples, and of Stuiver and Becker (1986) for the terrestrial charcoal sample. For calibration of the marine shell samples, we used a $\Delta \mathrm{R}$ value of $100 \pm 24$, a weighted average of empirically determined $\Delta \mathrm{R}$ values from Eniwetok, Hawaii and Society Islands (Stuiver, Pearson and Braziunas, 1986, Table 1). As in the case of ${ }^{14} \mathrm{C}$ samples from Lapita sites in the Mussau Islands (Kirch \& Hunt, 1988, p 162), we feel that this pooled value best represents a $\Delta R$ value for the tropical central Pacific. Calibrations and probability estimates were made using the Rev. 2.0 version of Stuiver and Reimer's FORTRAN microcomputer program (Stuiver \& Reimer, 1986).

Figure 1 displays the calibrated BP age ranges $(1 \sigma)$ for the seven samples from the Toaga site, in stratigraphic order. The samples are internally consistent with each other and with the stratigraphic sequence, with no significant inversions or anomalies.

Beta-25035 and -25673, which overlap at $2 \sigma$, indicate an age between 3700-3300 BP for the deposition of the calcareous sand beach deposit represented by Layer $\mathrm{V}$ in the main excavation. The isolated thin-ware ceramic sherds contained within this beach deposit are inferred to date to this same approximate time span. This age range is consistent with ${ }^{14} \mathrm{C}$ dates for initial Lapita occupation sites elsewhere in the southwest Pacific, including Tonga and Fiji (Kirch \& Hunt, 1988, Fig 2).

Beta-25034, -26464 and -25033 are in direct association with the prin-

TOAGA SITE $14 \mathrm{C}$ SEQUENCE

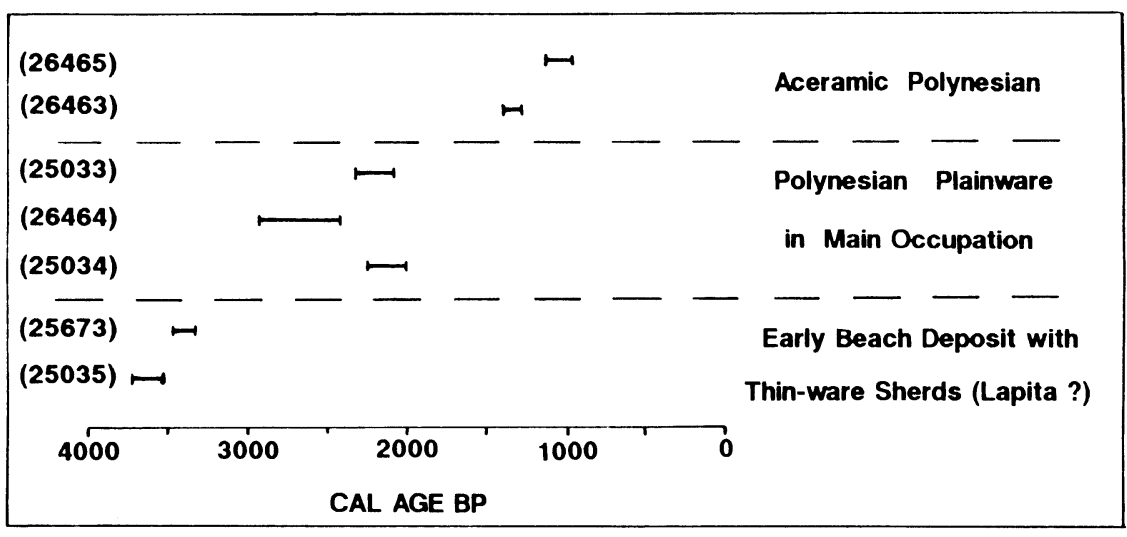

Fig 1. Calibrated BP age ranges $(1 \sigma)$ of ${ }^{14} \mathrm{C}$ samples from the Toaga site, Ofu Island, in stratigraphic order, with major cultural associations noted 
cipal occupation deposit in Layer II of the main excavation, and with its correlated stratigraphic deposit in test excavation Unit 10. A fourth sample in association with ceramics was obtained in 1986 during the excavation of a test unit near the land-fill operation, and yielded a ${ }^{14} \mathrm{C}$ age of $2350 \pm 50$ (Hunt \& Kirch, 1987, p 418). Together, all four samples in association with Polynesian Plainware ceramics, fishhooks and other cultural artifacts indicate a time span of ca 2500-1900 BP for this main occupation phase.

Beta-26463 was obtained from the base of an aceramic occupation deposit seaward of the main excavation trench, and overlying a calcareous beach deposit stratigraphically capping the Polynesian Plainware occupation in the main trench. Its age range of 1389-1287 BP indicates that the inhabitants of Ofu Island had ceased manufacturing or using pottery by the mid-first millennium AD.

Beta-26465 dates the base of an aceramic habitation platform constructed essentially on the present ground surface (and thus, overlying the midden from which Beta-26463 was obtained). The age of 1122-950 BP indicates that the alternating marine-terriginous (beach ridge-colluvial slope) depositional sequence of the Toaga site had been completed by this time period, with the construction of permanent habitation features on the modern landscape.

\section{CONCLUSIONS}

The suite of $8{ }^{14} \mathrm{C}$ age determinations from the Toaga site $(7$ reported herein, plus 1 additional date obtained in 1986 (Hunt \& Kirch, 1987)) provide a stratigraphically consistent chronologic sequence for human occupation of Ofu Island, spanning the period from ca 3700-3300 BP up to the modern era. This sequence has the following significant implications for Polynesian prehistory:

1) Although only a few small thin-ware sherds were recovered from the basal Layer $\mathrm{V}$ beach deposit, their stratigraphic context is secure, sealed under the massive colluvial deposit of Layer III. We believe that the sherds represent the periphery of a primary occupation area lying further inland of the main excavation trench, and now buried under as much as $5-15 \mathrm{~m}$ of colluvium. The sample of sherds is too small to determine, on stylistic criteria, whether they represent Lapita pottery, but the associated ${ }^{14} \mathrm{C}$ ages of Beta-25035 and -25673 are wholly consistent with other ${ }^{14} \mathrm{C}$ dates from Lapita sites in Tonga and Fiji (Kirch \& Hunt, 1988). Pending further excavations at Toaga to obtain a larger sample of this early thin-ware pottery (planned for 1989), we believe it is reasonable to tentatively conclude that the human colonization of Ofu Island was effected by a Lapita population in the mid-third millennium BC. This extends the known eastern boundary of the Lapita cultural complex from Western Samoa to the Manu'a group, and reinforces the emerging picture of the Lapita dispersal as a very rapid phenomenon. It further suggests that the true eastern boundary of the Lapita distribution may not yet be archaeologically attested.

2) Four ${ }^{14} \mathrm{C}$ dates in direct association with Polynesian Plainware ceramics and other artifacts indicate that this phase of Samoan prehistory 
extended from ca 2500-1900 BP. These dates from Toaga are in close agreement with other ${ }^{14} \mathrm{C}$ ages from Plainware sites in Western Samoa (Green \& Davidson, 1974; Jennings \& Holmer, 1980). Thus, the phase of Plainware production and use was contemporaneous throughout both western and eastern parts of the archipelago.

3) Two ${ }^{14} \mathrm{C}$ dates (Beta-26463 and -26465) from aceramic cultural contexts indicate that the production and use of pottery on Ofu Island had ceased sometime between ca 1900 and 1300 BP. These dates are consistent with the interpretation of Green and Davidson (1974) that pottery use in Western Samoa ended by ca AD 300.

\section{ACKNOWLEDGMENTS}

The 1986 phase of the Manu'a Archaeological Project was funded by a grant from the Historic Preservation Program, Department of Parks and Recreation, Government of American Samoa. We thank Stan Sorensen, Historic Preservation Officer, for his substantial assistance. We are also indebted to High Chief Aolaolagi Soli, District Governor of Manu'a, and other traditional chiefs and landowners of Ofu for their permission to conduct archaeological research on the island. Additional funds for radiocarbon dating were provided by the Burke Museum Director's Fund.

\section{ARCHAEOLOGIC SAMPLES}

\section{Ofu Island series}

\section{Beta-25033. Toaga}

$2640 \pm 80$

Marine shell (Turbo setosus, 71g) from Unit 6, Layer IIA-1. Comment: specimen represents culturally-deposited food remains (midden) assoc with earth oven feature and small quantities of Polynesian Plainware ceramics. Cal BC 362 (244) 145 at $1 \sigma$; cal BP 2311 (2193) 2094 at $1 \sigma$.

\section{Beta-25034. Toaga}

Marine shell (Turbo setosus, 70g) from Unit 6, Layer IIB. Comment: specimen represents culturally-deposited food remains (midden) in primary occupation deposit containing Polynesian Plainware ceramics, shell fishhooks and other artifacts. Cal BC 295 (161) 58 at $1 \sigma$ : cal BP 2244 (2110) 2007 at $1 \sigma$.

\section{Beta-25035. Toaga}

Marine shell (Asaphis violascens, Lunella cinerea, 48g) from Unit 6, Layer V, $314 \mathrm{~cm}$ below surface. Comment: specimens consist of naturallydeposited marine shell in a beach deposit also containing isolated thin-ware ceramic sherds. Marine shell retained surface coloration, and was not water-rolled, indicating deposition soon after death. Cal BC 1765 (1682) 1600 at $1 \sigma$; cal BP 3714 (3631) 3549 at $1 \sigma$. 
Beta-25673. Toaga

$3620 \pm 80$

$\delta^{13} \mathrm{C}=+2.2 \% 0$

Marine shell (Phalium sp, 45g) from Unit 1, Layer V, $290 \mathrm{~cm}$ below surface. Comment: specimen consists of a single whole shell, not waterworn and with original coloration, naturally deposited in beach deposit also containing isolated thin-ware ceramic sherds. Cal BC 1526 (1441) 1377 at $1 \sigma$; cal BP 3475 (3390) 3326 at $1 \sigma$.

Beta-26463. Toaga

$1910 \pm 50$

Marine nhell (Turbo setosus, $72 \mathrm{~g}$ ) from Unit 3, Layer II-4, $40-70 \mathrm{~cm}$ below surface. Comment: specimen consisted of a single large shell, with apertural margin displaying chipping, due to cultural removal of operculum. Represents basal contact of cultural, aceramic midden deposit with underlying sterile beach sand. Cal AD 561 (620) 663 at $1 \sigma$; cal BP 1389 (1330) 1287 at $1 \sigma$.

\section{Beta-26464. Toaga}

$2620 \pm 140$

Charcoal flecks (colln weight ca $1 \mathrm{~g}$, yielding $0.2 \mathrm{~g}$ final carbon after pretreatment) from Unit 10, Layer IIB occupation, $70-80 \mathrm{~cm}$ below surface. Comment: assoc with Polynesian Plainware ceramics. Sample was given extended counting time. Cal BC 967 (801) 454 at $1 \sigma$; cal BP 2916 (2750) 2403 at $1 \sigma$.

\section{Beta-26465. Toaga}

$1600 \pm 70$

Marine shell (Turbo setosus, $66.4 \mathrm{~g}$ ) from Unit 13, Layer III-3, 35-45cm below surface. Comment: sample consisted of 1 nearly complete shell and 2 smaller fragmentary shells, all displaying culturally-induced fractures and chipping. Exterior of all shells were stained light-gray from inclusion in cultural midden deposit. Specimens assoc with aceramic cultural midden near base of pebble-paved house platform. Cal AD 828 (914) 1000 at $1 \sigma$; cal BP $1122(1036) 950$ at $1 \sigma$.

\section{REFERENCES}

Finney, B, 1985, Anomalous westerlies, El Nino, and the colonization of Polynesia: Am Anthropologist, v 87, p 9-26.

1988, Voyaging against the direction of the trades: A report of an experimental canoe voyage from Samoa to Tahiti: Am Anthropologist, v 90, no. 2, p 401-405.

Green, R C, 1979, Lapita, in Jennings, J, ed, The prehistory of Polynesia: Cambridge, Massachusetts, Harvard Univ Press, p 27-60.

Green, R C and Davidson, J M, 1974, A radiocarbon and stratigraphic sequence for Samoa, in Green, R C and Davidson, J M, eds, Archaeology in Western Samoa, vol II: Auckland Inst \& Mus Bull, v 7, p 212-224.

Hunt, T L and Kirch, P V, 1987, Radiocarbon dates from two coastal sites in the Manu'a Group, American Samoa: Radiocarbon, v 29, no. 3, p 417-419.

1988, An archaeological survey of the Manu'a Islands, American Samoa: Jour

rwin, G, 1981, How Lapita lost its pots: The question of continuity in the colonization of Polynesia: Jour Polynesian Soc, v 90, p 481-494.

Jennings, J D and Holmer, R N, 1980, Archaeological excavations in Western Samoa: Pacific Anthropological Records, v 32. 
Kirch, P V, 1984, The evolution of the Polynesian chiefdoms: Cambridge, England, Cambridge Univ Press. p $9-40$.

1986, Rethinking East Polynesian prehistory: Jour Polynesian Soc, v 95,

Kirch, P V and Hunt, T L, 1988, Radiocarbon dates from the Mussau Islands and the Lapita colonization of the southwestern Pacific: Radiocarbon, v 30, no. 2, p 161-169.

Kirch, P V, Hunt, T L and Tyler, J, ms in prep, Landform change and early Polynesian occupation on Ofu Island, American Samoa.

Ottino, P, 1985, Un site ancien aux iles Marquises: l'abri-sous-roche d'Anapua, à Ua Pou: Jour Soc Oceanistes, v XLI, no. 80, p 33-37.

Stuiver, M and Becker, B, 1986, High-precision decadal calibration of the radiocarbon time scale, AD 1950-2500 BC, in Stuiver, $\mathrm{M}$ and $\mathrm{Kra}, \mathrm{R} \mathrm{S}$, eds, Internatl ${ }^{14} \mathrm{C}$ conf, 12 th, Proc: Radiocarbon, $v$ 28, no. 2B, p 863-910.

Stuiver, M, Pearson, G W and Braziunas, T, 1986, Radiocarbon age calibration of marine samples back to $9000 \mathrm{cal} \mathrm{BP}$, in Stuiver, $\mathrm{M}$ and $\mathrm{Kra}, \mathrm{R} \mathrm{S}$, eds, Internat ${ }^{14} \mathrm{C}$ conf, 12 th, Proc: Radiocarbon, v 28, no. 2B, p 980-1021.

Stuiver, M and Polach, H A, 1977, Discussion: Reporting of ${ }^{14} \mathrm{C}$ data: Radiocarbon, v 19, no. 3, p 355-363.

Stuiver, $\mathrm{M}$ and Reimer, $\mathrm{P}$ J, 1986, A computer program for radiocarbon age calibration, in Stuiver, $\mathrm{M}$ and $\mathrm{Kra}, \mathrm{R}$ S, eds, Internatl ${ }^{14} \mathrm{C}$ conf, 12 th, Proc: Radiocarbon, v 28 , no. $2 \mathrm{~B}$, p 1022-1030.

Terrell, J, 1986, Prehistory in the Pacific Islands: Cambridge, England, Cambridge Univ Press. 